Rhode Island College

Digital Commons @ RIC

2016

\title{
Increasing Staff Nurse Knowledge Related to Organ and Tissue Donation: A Quality Improvement Project
}

Carly G. Shields-Pirri

Rhode Island College

Follow this and additional works at: https://digitalcommons.ric.edu/etd

Part of the Nursing Commons

\section{Recommended Citation}

Shields-Pirri, Carly G., "Increasing Staff Nurse Knowledge Related to Organ and Tissue Donation: A Quality Improvement Project" (2016). Master's Theses, Dissertations, Graduate Research and Major Papers Overview. 153.

https://digitalcommons.ric.edu/etd/153

This Major Paper is brought to you for free and open access by the Master's Theses, Dissertations, Graduate Research and Major Papers at Digital Commons @ RIC. It has been accepted for inclusion in Master's Theses, Dissertations, Graduate Research and Major Papers Overview by an authorized administrator of Digital Commons @ RIC. For more information, please contact digitalcommons@ric.edu. 



\section{INCREASING STAFF NURSE KNOWLEDGE RELATED TO ORGAN AND TISSUE DONATION: A QUALITY IMPROVEMENT PROJECT}

A Major Paper Presented

$$
\text { by }
$$

Carly G. Shields-Pirri

Approved:

Committee Chairperson

Committee Members

(Date)

(Date)

(Date)

Director of Master's Program

(Date)

Dean, School of Nursing 
INCREASING STAFF NURSE KNOWLEDGE RELATED TO ORGAN AND TISSUE DONATION: A QUALITY IMPROVEMENT PROJECT

Carly G. Shields-Pirri

A Major Paper Submitted in Partial Fulfillment

of the Requirements for the Degree of

Master of Science in Nursing

in

The School of Nursing

Rhode Island College

2016 


\begin{abstract}
Initially viewed as doubtful and plagued with uncertainty, the process of organ/tissue transplantation has proved to be one of the most successful medical breakthroughs of modern medicine. From the initial documented success of organ/tissue donation and subsequent transplantation, the need for organ/tissue donation exceeds the available resources. Many individuals are aware of the need for organ/tissue donation for lifesaving transplantation but do not take the necessary steps to become a donor or share that desire with family and/or loved ones. There are no national programs or efforts in place for standardized nursing education about organ/tissue donation and transplantation. The purpose of this quality improvement project was to increase nurses' knowledge of the New England Organ Bank (NEOB) guidelines for organ and tissue donation. The project design was a pre-test, an educational program, and post-test. Twenty-two nurses completed the pre-test component $(\mathrm{N}=22,63 \%)$ and fourteen nurses completed the posttest $(\mathrm{N}=14,40 \%)$. Results indicated nurses had better overall better knowledge of organ donation then specifically tissue donation. Nursing staff demonstrated increased knowledge of NEOB guidelines and the nurse's role in timely reporting after the educational program on organ donation with improved post-test over pre-test scores. Future replication of education related to NEOB guidelines for donation of organs and tissues and nurse responsibility for timely reporting should increase emphasis on the area of tissue donation. A need based assessment to determine specific areas of deficit may aid in promoting positive outcomes in future replication.
\end{abstract}




\section{Acknowledgements}

Although unable to thank all those who have contributed to the completion and success of this academic journey this writer would like to thank Patti Calvert for being the first reader for this major paper, Cynthia Padula for being the second reader and Julia Twining for being the third reader. Thank you for your utmost patience as well as support and guidance throughout this writing process. I am grateful for your unwavering assistance. To the nursing staff on Tower-4 at Newport Hospital, thank you for your time and participation in this project.

To my husband Alex, you have been by my side since the very beginning of my nursing journey. Through undergraduate and graduate school you have never let me give up continuing to push me onward. For your incredible patience, support and love I will be forever grateful. To my mother Sandra, it was your encouragement, which led me to advance my nursing career and pursue the Master's Degree. You never let me give up on myself always believing in me even when others may have felt different. To my dad Rob, you were always my biggest fan and supporter in life, never ceasing to believe in me matter how simple or large the task. To my lifelong best friend Ashley, thank you for always being my go-to person and source of support. I will never be able to thank you enough for always being there for me through every turn in life.

To Christie Bowser, Jessi Corrente and Ashlee Viveiros, thank you. Together we have laughed and cried, ultimately proving that perseverance does lead to success. You are remarkable women and nurses who should be proud of the academic success you have achieved. To the rest of my family and friends, you all hold a special place in both my life and heart. I am thankful for the guidance, kindness, love and support you have provided to me always. Thank you. 


\section{Table of Contents}

Background/Statement of the Problem ............................................................... 1

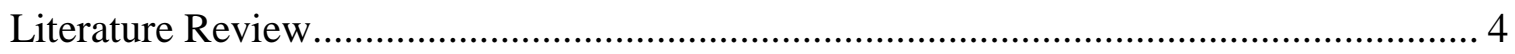

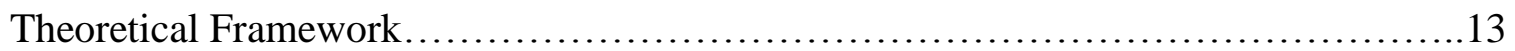

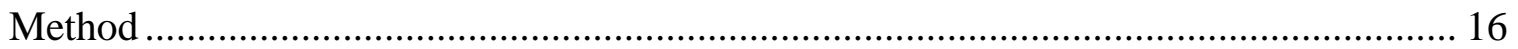

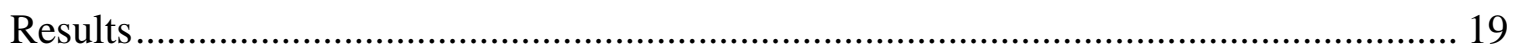

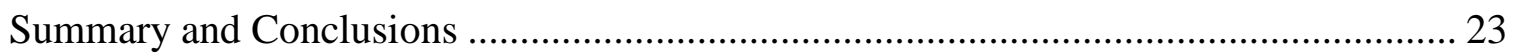

Recommendations and Implications for Advanced Nursing Practice .......................... 26

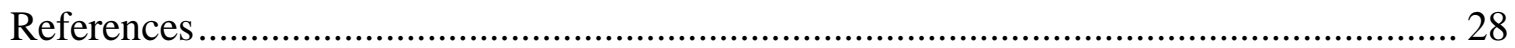

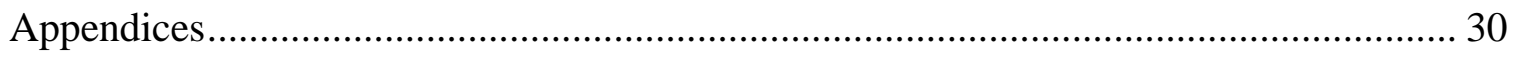




\section{INCREASING STAFF NURSE KNOWLEDGE RELATED TO ORGAN AND TISSUE} DONATION; A QUALITY IMPROVEMENT PROJECT

\section{Background/Statement of the Problem}

Individuals are living longer. According to the Centers for Disease Control and Prevention (CDC), the average life expectancy at birth for both males and females born in the United States was 47.3 years in 1900 and has increased to 78.7 years as of 2010 (Prevention, 2015). Many diseases, which at one time were considered terminal, are now better managed allowing individuals to live longer with chronic illness. Scientific advances and medical breakthroughs such as organ/tissue transplantation allow individuals who were previously considered to be "end of life," the opportunity to live longer with an improved quality of life. Initially experimental and beset with failed attempts, organ/tissue donation and transplantation can be considered one of the greatest successes of modern medicine (Roza, Medina, Barbosa, \& Schirmer, 2010).

The New England Organ Bank (NEOB) is the organ procurement organization (OPO) which covers the New England states (Connecticut, Maine, Massachusetts, New Hampshire, Rhode Island and Vermont) as well as Bermuda. Bermuda is included in the NEOB OPO since Massachusetts, with two hours flight time to Bermuda, is one of the nearest air transport destinations. The New England Organ Bank estimates one individual is added to the national organ transplant waiting list every ten minutes and currently 124,000 individuals are awaiting organ transplants in the United States (Bank, 2014). Many more individuals are waiting for tissue donation, such as skin, blood vessels, tendons, bone, heart valves and cornea. Whether organ or tissue, both could be a lifesaving measure (Bank, 2014). The United Network of Organ Sharing reports that one 
organ donor has the ability to save up to eight lives (Sharing, 2015). Twenty-one individuals die each day across the United States as they wait for life-saving organ or tissue donation (RIDMV, 2015). The number of individuals in need of organ/tissue donation continues to climb while the number of donors does not. The consequence is that roughly only one out of five individuals in need of an organ or tissue will become a recipient (Durie, 2006). This unmet need for organ/tissue for transplantation affects thousands of individuals on the waiting list and their families. Education targeted at healthcare professionals and their role in procurement could increase the number of potential donors.

The need for organ and tissue availability for transplantation is complicated by specific and non-negotiable guidelines for reporting potential organ/tissue donors at time of death in and out of medical care settings. Guidelines are in place for who can and who cannot become an organ/tissue donor as well as the timeframe in which referrals must be made from the medical center to the organ bank after death. According to the NEOB website, in 2014 organs were harvested from 267 donors resulting in a total of 731 organ transplants spanning 55 hospitals in New England (Bank, 2015). By providing nursing staff education on the NEOB guidelines for organ/tissue donation and NEOB's role working with grieving families, nurses may better understand and fulfill their vital role in reporting potential organ/tissue donors to NEOB.

Currently, there is no formal education provided in orientation or annual competencies for nurses working at Newport Hospital about reporting requirements and the NEOB guidelines for donation. The purpose of this quality improvement project is to 
improve staff nurse knowledge related to organ and tissue donation with the goal to increase reporting to NEOB.

Next, a review of relevant literature will be discussed. 


\section{Literature Review}

The literature review was conducted using the following databases searching from 1991-2015: Cumulative Index and Allied Health Literature (CINAHL), Medline, Pub Med and Google Scholar. Keywords included: organ transplant, organ, tissue, donation, organ/tissue donation, nurse, theory and Malcolm Knowles.

\section{Organ/Tissue Donation and Transplantation, a Historical Overview:}

Since the initial success of organ/tissue transplantation, the need for donation has exceeded the available supply. The need continues to grow but the available supply does not (Durie, 2006). In 1984 the United States Congress passed the National Organ Transplant Act (NOTA) resulting in the creation of the Organ Procurement and Transplantation Network (OPTN), a non-profit organization. The overall goal of the OPTN was to develop a national organ registry and safe, ethical guidelines to ensure a better match between the available organs/tissues and recipients (Durie, 2006). The OPTN was responsible for the creation and development of a registry referred to as the United Network of Organ Sharing (UNOS) (Durie, 2006). The United Network of Organ Sharing became the national system used for sharing available organs and tissues. Organs able to be donated include the heart, kidneys, lungs, pancreas and intestines (Sharing, 2015).

The United Network of Organ Sharing, a non-profit organization was created in the United States to oversee donation and transplantation. Under a United States government contract UNOS uses this computerized tracking system to identify potential organ/tissue donors as well as recipients - ultimately matching donors to recipients after patient death. When a donor organ has been identified potential registered recipients are generated into a ranked list. Factors such as geography, waiting time, medical necessity, 
organ size, blood type and tissue type are determinants of recipient selection (Sharing, 2015).In our region medical professionals are in day-to-day contact regarding possible donation with the NEOB; however the primary oversight for organ donation and procurement across the United States is the function of UNOS. A computerized tracking system was created by UNOS and has been viewed as a model for other transplant systems worldwide (Sharing, 2015).

The UNOS website, www.unos.org, provides up-to-date and easy-to-read information for public education. Any individual can be an organ/tissue donor regardless of age or background: however medical status and health/illness assessed at time of death determines if tissues or organs are viable for donation (Sharing, 2015). NEOB is the oldest independent organ procurement organization (OPO) in the United States as well as the federally appointed OPO for the New England states (Sharing, 2015). The New England Organ Bank is also the OPO for Bermuda (Bank, 2015). NEOB is regulated by the Centers for Medicare and Medicaid Services and works alongside UNOS. Although geographically distant the NEOB also provides coverage and services to Bermuda. The NEOB includes 9 regional offices and 12 transplant centers partners - hospitals where life-saving transplant procedures occur. Ultimately, UNOS oversees the actions of the NEOB both regionally and nationally through its computerized database (Sharing, 2015). UNOS is responsible for creating and implementing policy related to the allocation of organs/tissues for transplantation. When NEOB as an OPO receives an organ/tissue for donation UNOS is contacted to determine the best match to a recipient (Bank, 2014).

To ensure safe and ethical donation and transplantation of tissues The Human Tissue Ace of 2004 was enacted. This act replaced the previous Human Tissue Act of 
1961 to ensure a consistent framework of legislation related to whole human body donation, as well as the process of taking, storage and use of human organs and tissues. This act also sets guidelines for organ/tissue harvesting and storage after death. Another major component of the Human Tissue Act of 2004 is to oversee licensure, activities and issue codes of practice (Gumbley\& Pearson, 2006). Current UNOS guidelines require that the designated OPO be notified within one hour of death and information provided for the OPO to determine if a patient is suitable to be an organ donor. Donation of tissue alone can both improve life and save life for the recipient (Gumbley \& Pearson, 2006). Donation of tissue specifically includes: cornea and sclera of eyes, skin, bone, tendons and heart valves. Tissue donation often occurs after patient death however bone may be taken from a living donor (Gumbley\& Pearson, 2006).

A corneal transplant can provide sight to an individual and transplanted skin may assist a burn patient heal or help reduce pain (Gumbley\& Pearson, 2006). Skin donation can aid in cleft lip repair, hernia repair, dental procedures or reconstructive surgeries post cancer treatment such as a mastectomy. Saphenous and femoral veins from lower extremities can be grafted to increase blood flow to the heart in a cardiac surgery or used in peripheral bypass surgery to increase blood supply to the foot/leg, which may save a limb (Bank, 2014). Current UNOS guidelines allow that the designated OPO be notified within 24 hours of death and information provided for the OPO to determine if a patient is suitable to be a tissue donor.

Readily available information about organ/tissue donation and NEOB guidelines may benefit nurses on medical-surgical units, where sudden and unexpected death occurs less frequently than emergency departments or intensive care units. Providing nurses on 
the medical/surgical units with information about organ/tissue donation has the potential to increase identification of organ/tissue donors.

\section{Organ/Tissue Donation \& Transplantation: Current Statistics:}

The New England Organ Bank, the New England regional affiliate of UNOS is a resource for organ/tissue donation education and procurement. The New England Organ Bank reports that 123,000 individuals in the United States are in need of a lifesaving organ transplant. It is estimated that 21 individuals die each day waiting for a needed organ. In 2014 alone 29,532 organ transplants were performed in the United States and the NEOB estimates that 30,000 donations of tissue have been used to heal and possibly save lives in 2014. The need for tissue donation continues to rise along with the need for organs with over one million tissue transplants occurring annually (Bank, 2014). Each

year, more than 20,000 individuals succumb to traumatic brain death however only $15 \%$, or about 3,000 people will become cadaver organ and tissue donors (Matten et al., 1991). While many individuals are aware of organ transplantation and donation the numbers associated with knowing/understanding tissue donation are lower. Roughly $98 \%$ of individuals report a knowing and/or understanding of organ donation yet only $86 \%$ report a knowing/understanding of tissue donation (Bank, 2014).

There is no associated fee for an individual to be an organ and/or tissue donor. Contrary to some fears about organ donation, patients who are identified as organ donors receive the same medical care as those who are not (DMV, 2015). No religions forbid the donation of organs or tissues and rather consider donation an act of charity (Sharing, 2015). To become an organ donor in the state of Rhode Island one can do so either online (www.dmv.org) or at the Department of Motor Vehicles. Organ donor status is then 
printed on an individual's driver's license. The UNOS and NEOB websites provide education onto how to become an organ donor and provide fact sheets along with Q/A format of information. Individuals are able to register as an organ donor and specify their wishes at both the NEOB website and UNOS website. Individuals who do not wish to be donors themselves are able to make financial contributions through UNOS and NEOB (Bank, 2015). Each website advises individuals to inform family and loved ones of their choice to be an organ donor. Although donors of organs/tissue may be any age, one must be eighteen years old to deem themselves a donor (RIDMV, 2015).

\section{Organ/Tissue Donation \& Transplantation: Need for Education \& Improvement}

Contributing to the inadequate supply of organs/tissues for transplantation is the lack of identification of potential donors. Individuals die each day that could possibly donate organs/tissues but are not reported to organ procurement organizations. Causes for under-reporting include lack of public awareness of the need for donation, lack of early conversations between those who wish to donate and family and healthcare providers and the reticence for medical/nursing professionals to discuss donation with patients/families before it is to late (Matten et al., 1991).

In a study conducted by Matten et al 1,683 nurses were asked to complete a 70 item questionnaire to assess their knowledge, attitudes and beliefs related to organ/tissue donation and transplantation. The goal of their 1988 research was to consider other causes for the shortage of organs/tissues available for transplantation. Results of the study identified barriers for nurses and physicians including inadequate knowledge of associated policies and procedures, perception of adding stress to surviving relatives/loved ones, lack of physician support reported by nurses and inexperience with 
organ/tissue request along with the associated emotional distress. Matten et al. also documented that a personal commitment to the process of donation/procurement assisted in promoting better outcomes. The research identified that younger nurse respondents were often less aware of the organ donation process. Additional indicators of lack of understanding or support included fear of the process of organ removal after death, religious beliefs, anxiety related to death and personal myths and/or superstition (Matten et al., 1991). Many medical centers have an ethics committee, which can serve as an additional source of support to nurses experiencing personal moral distress if religious or personal beliefs are in conflict with policies.

In 1988 patients receiving a needed organ or tissue was about 12,000. In 2010 that number had increased to 450,000 (Hoy, Alexander, \& Frith, 2011). Rates of organ/tissue donation and transplantation continue to rise. Educational programs for nurses about organ/tissue donation and transplantation may increase organ bank reporting and possibly increase available organs and tissue. A recent study conducted by Hoy, Alexander and Frith identified that many nurses working today began their careers in a time when organ/tissue donation and subsequent harvesting were in a "trial and error phase." Therefore their views and opinions may be very different from younger nursing graduates who grew up in a world where transplantation is more common and successful. Identifying nurses' opinions, views and beliefs related to organ donation is important when developing educational programs related to organ and tissue procurement and donation (Hoy et al., 2011)

The research of Hoy, Alexander and Frith conducted a pre-experimental, pretest and posttest interventional study aiming to assess registered nurses attitudes related to 
organ/tissue transplantation before and after graduate-level course (Hoy et al., 2011). The required course was online and occurred over a five-week span of time and the pretest/post-test consisted of 18 survey questions. Topics included transplantation history basics, organ donation, immunosuppression and care required in the clinical setting for patients receiving organ/tissue transplant. Participants were required to complete online postings as well as course assignments; 30 nurses initially enrolled in the course and 30 nurses completed both the pre-test and post-test portion of the study. The educational intervention resulted in better outcomes when compared with the initial pre-test. Attitudes regarding advocacy for transplantation, confidence speaking with communities about organ donation, confidence in discussing transplantation with others and encouraging others to get involved in transplantation were most improved. When compared with pretest scores post-test scores increased from 66 to 90 in regards to advocacy for transplantation and an increase from 36 to 64 was noted in regards to confidence speaking with communities about organ donation. Scores for confidence in discussing transplantation with others increased from 43 to 87 and encouraging others to get involved in transplantation increased from 73 to 86 (Hoy et al., 2011).

The University of Wisconsin Hospitals and Clinics organ procurement organization (UWHC-OPO) received a two year grant from the United States Department of Health and Human Services to study the effect of student run organizations ability to provide education related to organ/tissue donation as well as the process of joining donor registries (D'Alessandro, Peltier, \& Dahl, 2012). Throughout the two years the Collegiate American Marketing Association (CAMA) along with the UWHC-OPO utilized the internet and conducted the largest university-based social medial study to date. Utilizing 
interventions such as e-mail, social media and the projects website investigators were able to provide organ/tissue information to viewers for their project titled "AMASavesLives." Goals of the study were to identify barriers and/or opportunities to improve attitudes and behaviors related to organ/tissue donation, implementing a social media based intervention to increase education and knowledge of donor registries, measure such impact on individuals attitudes, behaviors and overall awareness as well as look to current organ donor registries and assess behaviors (D'Alessandro, Peltier, \& Dahl, 2012).

Results of the study indicated that positive attitudes about organ/tissue transplantation improve by directing educational programs to college students as well as student organizations. With the technology and social media of today, touching one individual has the potential to reach many others. The results of this specific college student run organization and the use of social media proved to be successful in accessing a wider demographic and subsequently a larger population of educated potential organ donors and/or recipients (D'Alessandro, Peltier, \& Dahl, 2012). A major result of this survey identified that information being dispersed needed to be relevant to the listener, in this case college students. While many participants may not have any experience with organ/tissue donation, they may have had a sick loved one or have been asked if they want to register themselves as a donor when applying for a driver's license. This study identifies the changing world we currently live in and illustrates one way of increasing education and understanding of an imperative topic of today's healthcare world (D'Alessandro, Peltier, \& Dahl, 2012). 
The purpose of this quality improvement project is to improve staff nurse knowledge related to organ and tissue donation and NEOB guidelines.

Next, the theoretical framework for this study will be discussed 


\section{Theoretical Framework}

The theoretical framework used for this quality improvement project is Malcolm Knowles' Adult Learning Theory. Knowles developed his theory of adult learning based on the concept of Andragogy believing adults learn differently than children (Smith, 2002). Defined by the Oxford Dictionary, andragogy is "the method and practice of teaching adults" (Press, 2015). In Knowles' original work (1950) he identified that when providing education and/or teaching the overarching goal is to produce a change in the behavior of the learner (Knowles, 1950). Knowles' further explained that teaching is not solely about ensuring a certain amount of information is covered in a lesson, but more to effect a desired change. The original work of Knowles indicates only four concepts; selfconcept, experience, readiness to learn and the idea of a learning shift from subjectcenteredness to problem-centeredness (Knowles, 1970).

In the first concept of his theory, self-concept, Knowles posits that as individuals grow and mature so does their self-concept. One is a dependent personality as a child, and develops into a self-directed individual with age. As individuals grow into adulthood they accumulate experience, which contributes to learning. Adults learn best when they are ready to learn; social roles and desires contribute to the process of adult learning. Adults also base learning on solving problems and look to immediate understanding. Adults want to correct problems and apply what is learned rather than children who apply what is learned later. Adults also are internally motivated through maturity; learning is desired (Smith, 2002). Knowles further explains that adult learners often want to learn;

they come from a place where they want to fill a void in knowledge and come willingly, not forced into academics, as are young school children (Smith, 2002). 
The original concepts developed by Knowles provide a background and an understanding of how to approach and teach adult learners. Knowles begins with selfconcept (Knowles, 1970). As children, attending school and learning is a primary responsibility - one identifies himself or herself as a student. However, once transitioned into adulthood individuals are able to define themselves; nurse, banker, mother, father, teacher, etc. An adult learner has developed and molded their own self-concept and is able to manage themselves and their life, as well as their desire to learn. Thus, they desire to be taught in a respectful environment - not reprimanded or treated as a child (Knowles, 1970).

Like each child, each adult has a different background and a different story to tell. However, unlike children adults have years of stories, which have molded them into adulthood as well as shaped and influenced decisions. Knowles explains that to a child, an experience is something that happens to them - but for an adult experience is what makes them. Experiences are defining characteristics to adults (Knowles, 1970). Experiences help adults in learning situations and allow them to better relate to new experiences. A major point Knowles expresses is that adults often have years of habits and isms, which cause them to be less open-minded in new learning scenarios (Knowles, 1970).

For children, it is believed they learn best in situations where what is being taught is required for the learner to advance into the next stage. Children take basic learning and build on it to advance and gain further knowledge. Similar to children who have periods of growth and development, adults require a readiness to learn in order to advance into each subsequent stage of life (Knowles, 1970). Unlike children who view learning with a 
sense of postponement, each year of education prepares for the following year. Adults tend to respond best to learning which provides a form of immediate gratification. Adults prefer to learn and to be taught in order to improve upon themselves, their profession and/or current way of life (Knowles, 1970).

Next, the methodology utilized will be discussed. 


\section{Method}

\section{Purpose}

The purpose of this quality improvement project was to increase staff nurse knowledge related to organ and tissue donation.

\section{Design}

The design of this quality improvement project was an educational program with a pre- and post- test.

\section{Participants and Site}

Project participants included nurses working on a twenty-nine bed medicalsurgical unit at Newport Hospital, a 129-bed community hospital. Registered nurses employed on the medical-surgical unit were asked to voluntarily participate in this quality improvement project $(\mathrm{N}=35)$.

\section{Procedures}

Administrative approval was obtained from the clinical nurse manager of the project unit. The Lifespan IRB and Rhode Island College IRB reviewed the project. Lifespan approved the project and deemed it "not research" in March, 2016. Rhode Island College approval was also obtained in March, 2016. All nurses employed on the specified unit were invited to participate. An informational letter was distributed to staff nurse mailboxes one week prior to the beginning of the project; additional informational letters were made available in both the staff lounge and unit manager's office (Appendix A). Flyers announcing the start of the project were also displayed in the staff lounge (Appendix B). 
One week after the informational letter was distributed, copies of a 10-question pre-test were placed in the staff break-room in a manila folder with the informational letter attached to the front. The pre-test/post-test is found in Appendix C. No identifying data was requested on the pre-test. Nurses placed completed tests in a locked box on the unit. A raffle ticket for a twenty-five dollar gift card was stapled to each pre-test. Nurses detached the raffle ticket from the pre-test, wrote their name on the raffle ticket and placed it in the same locked box. No other identifying information linked the name on the raffle ticket to an individual test. The twenty-five dollar Visa gift-card raffle was held at the end of the project. Nurses were given one week to complete the pre-tests. This writer and unit manager encouraged staff to participate in the project during morning huddle, staff meetings and at change of shift.

After one week, the pre-tests were removed from the unit and unit-based education began. Content included NEOB guidelines for organ and tissue donation and the nurse's role in timely reporting of patient death. Education was provided over the next week in brief presentations on the unit at change of shift and at staff meetings. Presentations by this writer and posted informational materials were provided by the NEOB and included: Timely Referral for Tissue Donation (Appendix D), NEOB Tissue Donation Fact Sheet (Appendix E), and NEOB Tissue Screening Worksheet (Appendix F).NEOB badge-tags were distributed to nurses to attach to their identification badges for quick reference (Appendix G). The badge-tags had limited information related to pretest/post-test questions.

At the end of the second week, educational sessions ended and all posters/informational materials were removed from the unit. Copies of the 10-question 
post-test were placed in the staff break-room in a manila folder with the informational letter attached to the front. No personal information was requested on the post-test. Nurses placed completed tests in a locked box on the unit. A raffle ticket for the twentyfive dollar gift card was stapled to each post-test. Nurses detached the raffle ticket from the pre-test, wrote their name on the raffle ticket and placed it in the locked box. No other identifying information linked the name on the raffle ticket to an individual test. Nurses had two chances to win the twenty-five dollar Visa gift-card raffle if they completed both the pre-test and post-test. Post-tests remained available on the unit for an additional week.

\section{Measurement}

This writer developed test questions based on NEOB-provided written guidelines for notification of NEOB after patient death. The identical 10-question pre-/post-test included multiple-choice, select all that apply and true/false format (Appendix C).

\section{Data Analysis}

To measure the effectiveness of this quality improvement project a descriptive statistical analysis was utilized to assess results. Overall answers (right and wrong) on the pre-test were analyzed and compared with post-test answers. Aggregate scores were compared. The desired outcome was to increase staff nurse knowledge related to organ and tissue donation, demonstrated by an increase in post-test scores over pre-test scores.

Next, the results of the project will be discussed. 


\section{Results}

Twenty-two nurses out of a potential thirty-five nurses on the project unit $(\mathrm{N}=22$, $63 \%$ ) completed the pre-test component of the project. Fourteen nurses out of a potential thirty-five $(\mathrm{N}=14,40 \%)$ attended the educational session and completed the post-test; a fifteenth post-test was incomplete and not included in post-test results. Questions number one, six, nine and ten were multiple-choice format questions. Questions number two, three, four and eight were "select all that apply" format questions and numbers five and seven were true/false questions. Comparison of test scores from the pre-test and post-test are illustrated in both Table 1 and Table 2.

Table 1illustrates the comparison of scores between the pre- and post-test.

\section{Table 1:}

Test Score Comparison Pre-Test/Post-Test

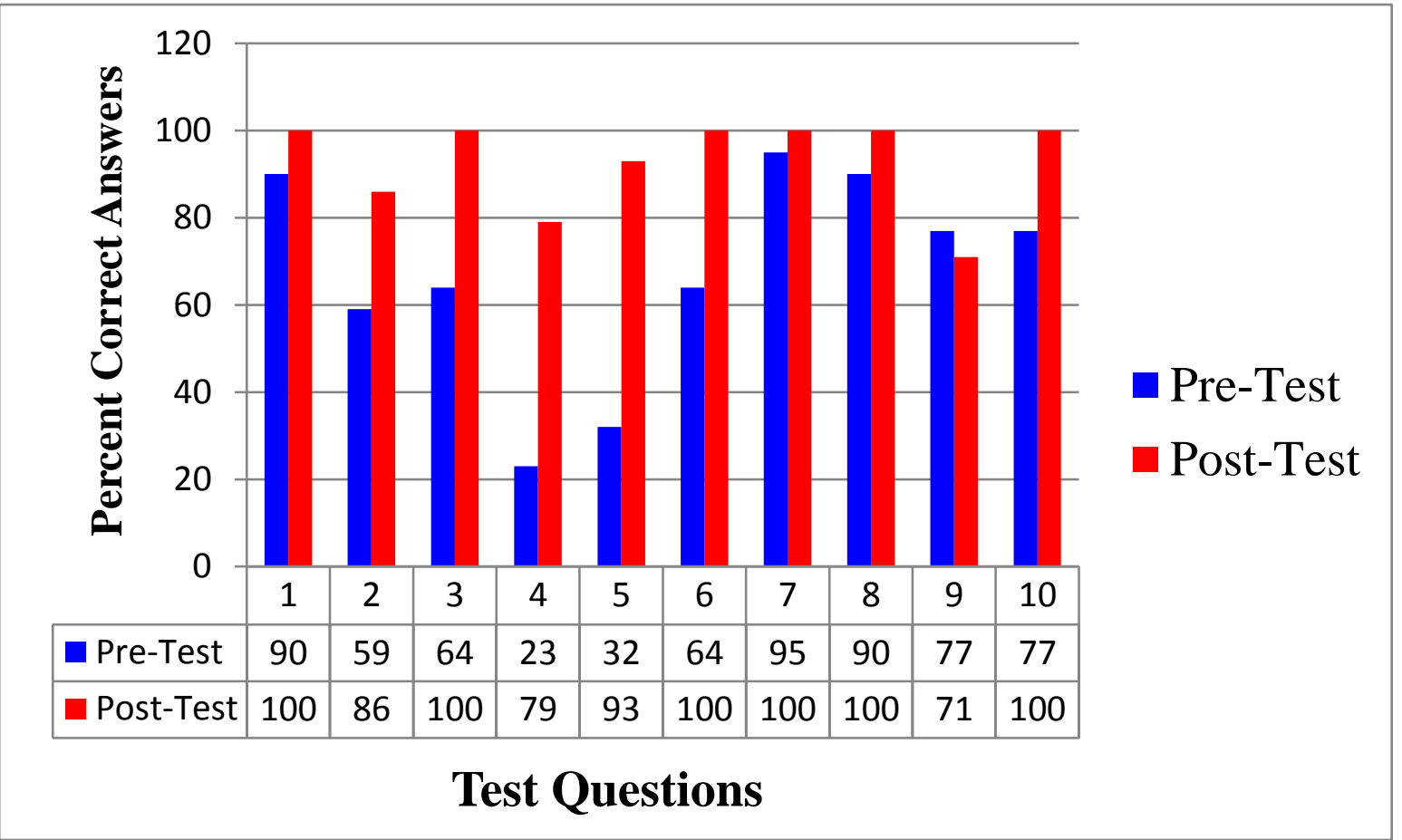


The majority of post-test scores improved in comparison to the pre-test score after education was provided. Noted improvement in some areas was achieved. While $90 \%$ $(n=20)$ of participating nurses correctly answered that timely reporting to NEOB for organ donation must occur within one hour of patient death on the pre-test, $100 \%(\mathrm{n}=22)$ of the nurses answered this question (question number one) correctly on the post-test. Nurses' recognition of the need to contact the NEOB within one hour of patient death is the first critical step to successful organ donation. Questions number four and five demonstrated the most improvement between the pre-test and post-test. Question number four asked the participant to identify specific items of patient information required by NEOB when reporting patient death. Most pre-test responses included some of the correct components of NEOB-required information, but only $23 \%(5 / 22)$ correctly identified all correct components of required information. After the educational intervention, $79 \%(11 / 14)$ of respondents were able to identify all components.

\section{Participant knowledge of staff nurse responsibility to provide NEOB} representatives with the deceased patient's next of kin name and contact information was poorly understood when assessed in question number five. Initially only $32 \%(7 / 22)$ answered correctly. After nurses were provided education, post-test scores notably increased to $93 \%(n=13)$.

Table 2 illustrates the actual number of correct answers as well as the percentage of correct answers for each question on the pre- and post-test. The number of correct responses for each question on the completed pre-test is displayed as the numerator and the total number of tests as the denominator $(\mathrm{N}=22)$ of a fraction. The number of correct responses for each question on the completed post-test is displayed as the numerator and 
the total number of tests as the denominator $(\mathrm{N}=14)$. The red numerical value represents percent score out of a total one hundred percent for each question.

\section{Table 2:}

Percentage/Score Breakdown of Test Score Comparison Pre/Post-Test

\begin{tabular}{|c|c|c|c|c|c|c|c|c|c|c|}
\hline $\begin{array}{l}\text { Question } \\
\text { Number }\end{array}$ & 1 & 2 & 3 & 4 & 5 & 6 & 7 & 8 & 9 & 10 \\
\hline $\begin{array}{c}\text { Pre-Test } \\
\% \\
\text { Correct } \\
(\mathrm{N}=22)\end{array}$ & $\begin{array}{l}20 / 22 \\
90 \%\end{array}$ & $\begin{array}{l}13 / 22 \\
59 \%\end{array}$ & $\begin{array}{l}14 / 22 \\
64 \%\end{array}$ & $\begin{array}{l}5 / 22 \\
23 \%\end{array}$ & $\begin{array}{l}7 / 22 \\
32 \%\end{array}$ & $\begin{array}{l}14 / 22 \\
64 \%\end{array}$ & $\begin{array}{l}21 / 22 \\
95 \%\end{array}$ & $\begin{array}{l}20 / 22 \\
90 \%\end{array}$ & $\begin{array}{l}17 / 22 \\
77 \%\end{array}$ & $\begin{array}{l}17 / 22 \\
77 \%\end{array}$ \\
\hline $\begin{array}{c}\text { Post-Test } \\
\% \\
\text { Correct } \\
(\mathrm{N}=14)\end{array}$ & $\begin{array}{l}14 / 14 \\
100 \%\end{array}$ & $\begin{array}{l}12 / 14 \\
86 \%\end{array}$ & $\begin{array}{l}14 / 14 \\
100 \%\end{array}$ & $\begin{array}{l}11 / 14 \\
79 \%\end{array}$ & $\begin{array}{l}13 / 14 \\
93 \%\end{array}$ & $\begin{array}{l}14 / 14 \\
100 \%\end{array}$ & $\begin{array}{l}14 / 14 \\
100 \%\end{array}$ & $\begin{array}{l}14 / 14 \\
100 \%\end{array}$ & $\begin{array}{l}10 / 14 \\
71 \%\end{array}$ & $\begin{array}{l}14 / 14 \\
100 \%\end{array}$ \\
\hline
\end{tabular}

Pre-test scores ranged from 23 to $95 \%$. After education $100 \%$ of staff nurses were able to answer six of the ten questions correctly. Questions number three and nine remained under the $80 \%$ answering correctly after education was provided to nursing staff. These questions required the participant to know multiple components of NEOB donation and reporting guidelines. The percentage of correct responses in question number nine not only remained below the $80 \%$ in the post-test, but decreased from $77 \%$ to $71 \%$ answering correctly.

Staff nurses were receptive to participation in the project but limitations were also evident. Patient census fluctuation on the project unit resulted in nurse staffing fluctuations, which may have contributed to lower post-test participation. Delivery of education without dedicated time for the educational session proved difficult. The 
selected method for education may have contributed to low participation. Future replication of this quality improvement project may benefit from exploring new, unique education forums such as social media and/or NetLearning to increase participation. Educating all staff on current transplantation success rates and needed donors may increase staff interest in their important role in organ donation. Seeking support for dedicated time for education may increase participation in the future.

Next, the summary and conclusions will be discussed. 


\section{Summary and Conclusions}

Education related to NEOB guidelines for timely referral after patient death regarding organ and tissue donation was identified as a need on the medical-surgical project unit. Prior to this quality improvement project no facility-wide or unit-specific staff education was in place regarding NEOB guidelines and staff nurse responsibility for timely reporting. An educational program was developed using NEOB guidelines for timely reporting of patient death and a pre-test/post-test was created to assess baseline and post-educational intervention knowledge. As illustrated in tables 1 and 2, scores on the pre-test were low with an overall mean score of $67 \%$. After staff education overall mean score increased by $26 \%$, to an overall mean score of $93 \%$.

Twenty-two nurses out of a potential thirty-five nurses on the project unit $(\mathrm{N}=22$, 63\%) completed the pre-test component. Fourteen out of a potential thirty-five nurses $(\mathrm{N}=14,40 \%)$ completed the post-test. A fifteenth post-test was incomplete and was excluded from the results. The educational component of the project occurred at staff huddles and brief interactions within the unit. Due to the project design and anonymity of nurse response on pre- and post- tests the number of nurses who completed all three components of the project can't be determined.

Questions that assessed knowledge of patient-specific medical information and family contact information were initially low with marked improvement after provided education. Questions associated with staff knowledge of NEOB tissue specific timeline of reporting guidelines increased from $64 \%$ on the pre-test to $100 \%$ on the post-test. However staff knowledge of specific tissues - eyes, heart valves, skin and bone/associated tissues -for donation decreased. Staff were able to identify some tissues 
but not all on the pre- and post-test. The percentage of correct answers, identifying all tissues for donation was $77 \%$ on the pre-test and only $71 \%$ on the post-test. Medicalsurgical staff nurse knowledge related to non-organ tissue donation is significant because these tissues - eyes, heart valves, skin and bone/associated tissues- are more likely to be accepted by NEOB from the study unit because of patient age, diagnosis, co-morbid conditions, lack of ventilator support to prolong/sustain life and the increased time-frame for tissue donation after patient death.

The project unit nurses expressed satisfaction with project and the need for provided education. Nurses told this writer "I got a zero on the pre-test, I did not know any of the answers". Positive feedback from nurses shared with this writer included "thank you for doing this - at my old job we weren't responsible for the calls and I had to no idea what to do" and "Thank you - this is very useful information."

Limitations were also evident. Decreased census resulted in nurse cancellation specifically during the education/post-test period. This was followed by a rapid influx of patients limiting time for staff nurse participation. Census fluctuations and staffing adjustments may have contributed to lower post-test participation. Delivery of education without dedicated time proved difficult. The lack of allocation of time pre-determined by unit management may have also contributed to low participation. Future replication of this quality improvement project may require validation of the utilized pre- and post-test as well as exploring different methods of delivering education to staff.

In conclusion, this project was successful in increasing nurses' knowledge. A needs-based assessment to determine specific areas of deficit may aid in promoting 
positive outcomes in future replication. Future planning for an educational program related to this topic should increase the emphasis on differences between organ and nonorgan tissue donation.

Next, recommendations and implications for Advanced Nursing Practice will be discussed. 


\section{Recommendations and Implications for Advanced Nursing Practice}

This program highlighted the need for medical/surgical unit staff nurses education on NEOB guidelines for timely referrals related to organ/tissue donation. Results demonstrated increased knowledge of NEOB timely referral guidelines between pre- and post-test scores. The advanced practice registered nurse (APRN), specifically the Clinical Nurse Specialist (CNS), is in a unique position to identify, promote and facilitate programs based on assessed or expressed educational needs. Utilizing strengths of the role that encompasses the patient, nurse and system, the CNS is able to promote best practice outcomes in a variety of settings. In this quality improvement project, the APRN student had the ability to assess hospital-wide and system-wide need for NEOB timely referral education to improve healthcare provider knowledge of reporting requirements and staff nurse reporting responsibility.

Nursing orientation and annual competency fairs provide traditional methods educating and assessing nurse knowledge. The NEOB timely referral guidelines information is concise and could easily be incorporated into orientation and/or annual competencies. Educational program tools and posters from this project could be incorporated into orientation and/or annual competencies. This may be accomplished through collaboration with NEOB representatives.

Exploring innovative technology and communication methods to more effectively communicate with staff will evolve in a rapidly changing healthcare environment. NetLearning is a now standard means of education and testing all staff. Not only is the APRN able to impact nurse specific change but throughout disciplines across the hospital and system. Viewed as an expert in the nursing profession, the APRN is able to influence 
practice throughout the healthcare system utilizing current evidenced based practice and best-practice models. The APRN role is uniquely positioned to collaborate with multiple disciplines, helping to ensure up-to-date uniform standards of care across organizations and systems. Collaborating with sister organizations to improve staff knowledge and participation in organ/tissue donation across the system is a goal after education is complete throughout the project site hospital.

Not only is the APRN in a unique role to assist in the provision of education to staff throughout the unit and/or system but may also contribute to the development and maintenance of associated policy. The APRN can collaborate with NEOB to ensure upto-date guidelines are reflected in policies and procedures for the unit, hospital and entire system. Ensuring the proper policy is in place aims to ensure compliance ultimately promoting positive outcomes and best practice. As science and medicine are consistently changing and evolving it is crucial for the APRN to remain up-to-date in regards to practice and policy/procedures.

As evidenced through discussion in the literature review component, there have been great strides associated with the success of organ/tissue donation and transplantation since the initial documentation. Future research related to this topic should focus primarily on consistent education for students in nursing programs as well as for other health professionals. The lack of consistent education contributes to an overall lack of knowledge and resulting inability to correctly respond in potential organ/tissue donation situations. Research into the creation of such uniform educational programs as well as ways to best distribute the education has the potential to reach many and increase positive outcomes. 


\section{References}

Bank, N. E. (2014). New England Organ Bank.” Retrieved June 16, 2015, from New England Organ Bank: www.neob.org

Centers for Disease Control. (2015). “Fast Stats Life Expectancy.” Retrieved June 16, 2015 (http://www.cdc.gov/nchs/fastats/life-expectancy.htm)

D'Alessandro, A., Peltier, J., \& Dahl, A. (2012). Use of social media and college student organizations to increase support for organ donation and advocacy: a case report. Progress in Transplantation, 22(4) 436-441. http://dx.doi.org/10.7182/pit2012920

DMV, R. (2015, June 16). DMV.org. Retrieved June 16, 2015, from DMV.org: www.dmv.org

Durie, C. (2006). Organ Donation: Process and Standards Leading to Transplant. Journal of Legal Nurse Consulting,17(4) 12-18.

Gumbley, E., \& Pearson, J. (2006). Tissue Donation: benefits, legal issues and the nurse's role. Nursing Standard, 21(1) 51-56.

Hoy, H., Alexander, S., \&Frith, K. (2011). Effect of transplant education on nurses' attitudes toward organ donation and plans to work with transplant patients. Progress in Transplantation, 21(4) 317-321.

Knowles, M. S. (1950). Informal Adult Education. New York: Association Press.

Knowles, M. S. (1970). The Modern Practice of Adult Education. New York: Association Press.

Matten, M., Sliepcevich, E., Sarvela, P., Lacey, E., Woehlke, P., Richardson, C., et al. (1991).Nurses' Knowledge, Attitudes and Beliefs Regarding Organ and Tissue Donation and Transplantation. Public Health Report, 106(2) 155-166. 
Press, O. U. (2015).Oxford Dictionaries, Language Matters. Retrieved July 17, 2015, from Oxford Dictionaries, Language Matters: http://www.oxforddictionaries.com/us/definition/american_english/andragogy

Roza, B. d., Medina, J., Barbosa, S., \&Schirmer, J. (2010). Organ Donation Procedures: an Epidemiological Study. Progress in Transplantation, 20(1). 88-95.

Sharing, U. N. (2015). United Network of Organ Sharing, Working Together Saving Lives. Retrieved July 17, 2015, from United Network of Organ Sharing, Working Together Saving Lives: www.unos.org

Smith, M. (2002). Malcolm Knowles, informal adult education, self-direction and andragogy. Retrieved July 1, 2015, from Malcolm Knowles, informal adult education, self-direction and andragogy: http://infed.org/mobi/malcolm-knowlesinformal-adult-education-self-direction-and-andragogy/ 


\section{Appendix A}

\section{Informational Letter \\ Rhode Island College}

\section{IMPROVING STAFF NURSE KNOWLEDGE RELATED TO ORGAN AND TISSUE DONATION: A QUALITY IMPROVEMENT PROJECT}

Tower-4 Nursing Staff:

My name is Carly Shields-Pirri. I am a Clinical Nurse Specialist student in the Masters in Nursing Program at Rhode Island College. As part of the Masters Project requirements I am currently conducting a quality improvement project on our unit. The purpose of this project is to improve nurses' knowledge related to the New England Organ Bank (NEOB) requirements for timely referral after patient death. In order to complete this quality improvement project I am asking the nurses working on Tower-4 to participate. Participation includes completion of an anonymous pre-test, attendance at an educational program and completion of an anonymous post-test. Research and information provided by the NEOB and will be utilized for this project. Posters and flyers will be placed on the unit which display information related to NEOB guidelines. Participant education will occur during unit council meetings and brief in-services on the unit. The overall goal of this project is to improve nurses' knowledge and understanding of the NEOB timely referral guidelines thus increasing timely reporting to the NEOB by staff nurses.

Participants will be given the opportunity to be entered into a raffle after completion of the pretest and post-test. The raffle will be held at the next scheduled unit council meeting at completion of the project. If you have any questions or concerns regarding this project please contact me at (401)4990985 or cshields@lifespan.org. You may also contact Patti Calvert, the major advisor of this project at (401) 456-6323 or pcalvert@ric.edu. You may also contact Dr. Cynthia Padula at Rhode Island College at 456-9720. I look forward to initiating this project on our unit and hope you will participate!

Thank you in advance for your time.

Carly G. Shields-Pirri 
Appendix B

Increasing Staff Nurse

Knowledge Related to Organ and Tissue Donation

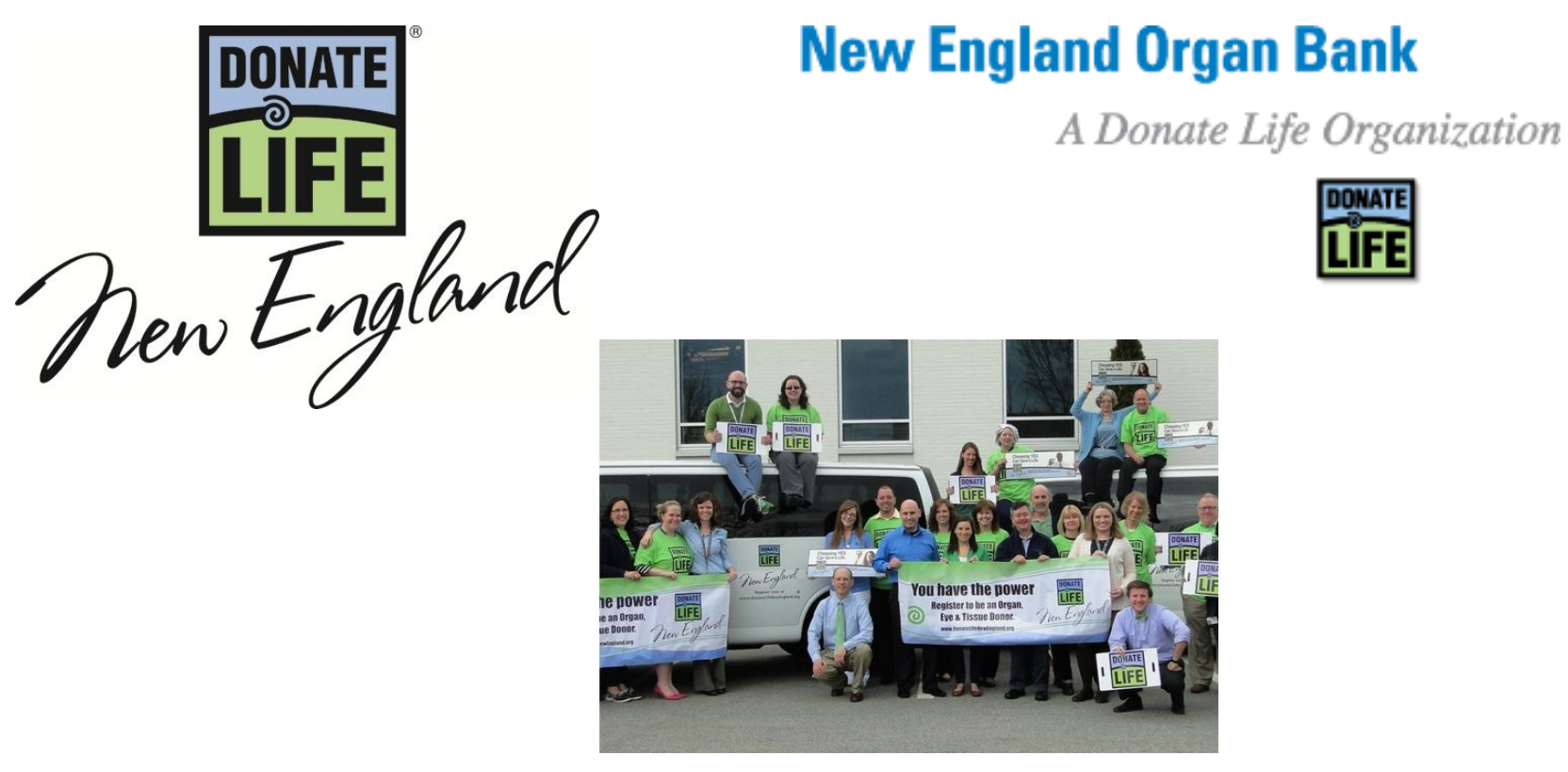

Education Sessions - April 2016

$\mathcal{N}$ ewport Hospital

Tower-4

For Further Information Contact Carly Shields-Pirri (401)499-0985 


\section{Appendix C}

1. To be considered a timely referral for organ donation, meeting New England Organ Bank(NEOB) guidelines how long after confirmed cardiac death does a nurse have to report the death? (Circle the best answer)
A: 30 minutes
B: One hour
C: Twenty-Four hours
D: Six hours

2. What information must be included when calling the NEOB for potential donation screening? (Circle all that apply)
A: Admitting diagnosis
B: Evidence of infection
C: Sexual orientation
D: Recent Surgical procedures

3. What information is required when reporting patient death to the NEOB? (Circle all that

apply)
A. Most recent and past three days temperature and source
B. Most recent WBC and blood cultures if available
C. BUN and creatinine

4. What elements of the patient's medical history are required by NEOB?

(Circle all that apply)

A: Past medical history

B: Current medical diagnoses

C: The patient's regular home medications (to the best of ability include OTC medications)

D: Patient's home address

5. The RN calling the NEOB to report a death also provides the NEOB representative with the patient's next of kin name and phone number. (Circle True or False)

True False

6. Unlike organ donation, tissue donation can be donated for up to hours after confirmed death. (Circle the best answer)
A: Twenty-four hours
B: Thirty-six hours
C: Twelve hours
D: Six hours 
7. As the nurse calling the NEOB for a referral you are responsible to initiate the donation discussion with deceased patients' next-of-kin. (Circle True or False)

True

False

8. What information does the NEOB require when calling in a patient death for possible donation? (Circle all that apply)

A: Patient name, date of birth, and medical record number

B: Date and time of death

C: Medial diagnosis and if patient was mechanically vented within 24 hours of death

D: Patient religion and funeral home contact

9. Circle the best answer indicating which of the following organs/tissues are eligible for donation.

A: Heart, lungs, brain tissue, bone \& associated tendons, blood vessels and heart valves

B: Heart, lungs, cornea, bone $\&$ associated tendons, blood vessels and heart valves

C: Heart, lungs, cornea, bone \& associated tendons, blood vessels, teeth, brain tissue and heart valves

10. What is the first step in the NEOB referral guidelines after patient death? (Circle the best

answer)

A: Alert patients family/next-of-kin that the patient has died and NEOB will be called

B: Contact the morgue

C: Call the NEOB at 1-800-446-6362 to alert them of patients' death

D: Alert the predetermined funeral home of patient death 


\section{Appendix D}

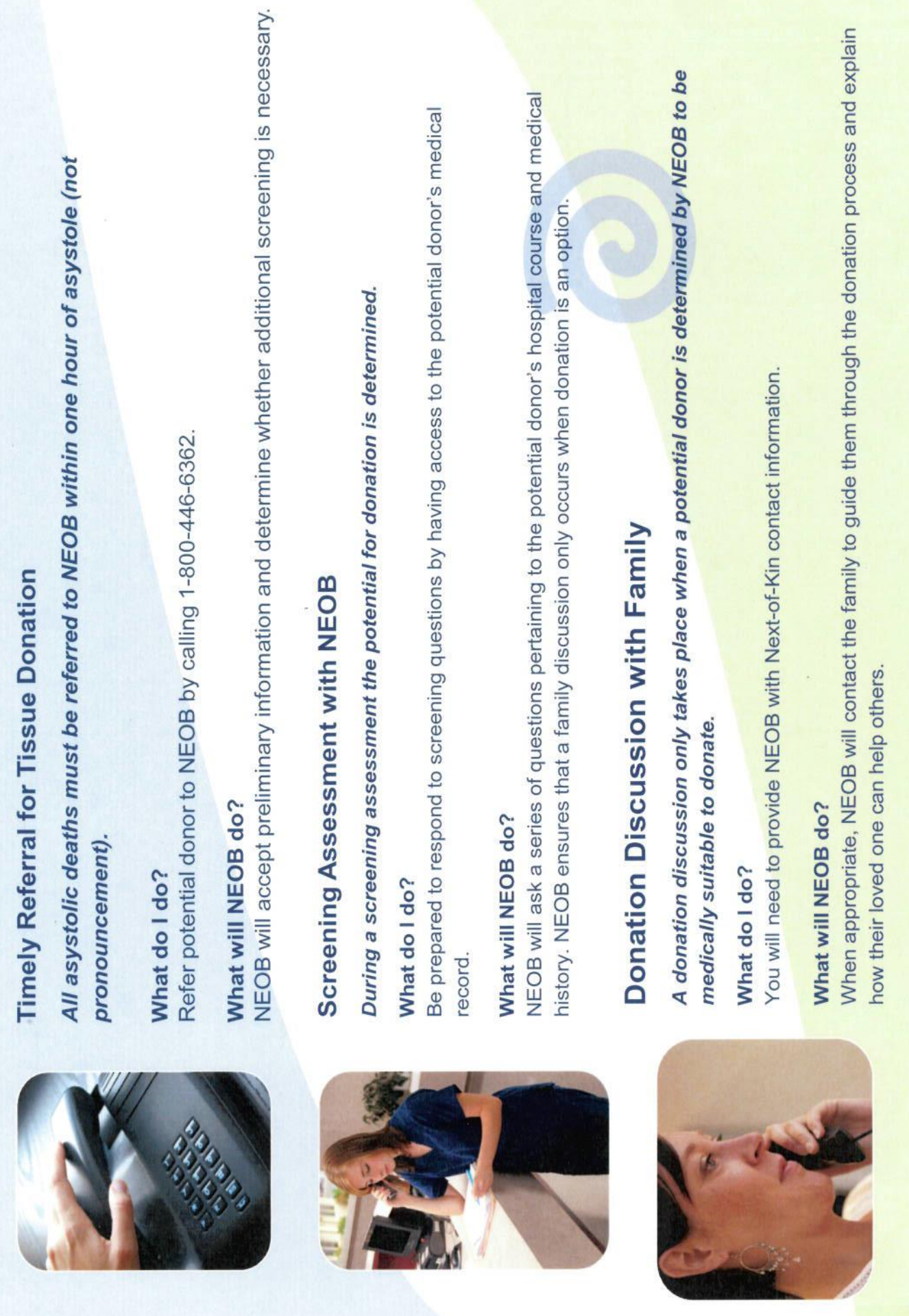




\section{Appendix E}

The following is a list of tissues that can be donated and the clinical indications of each:

\section{$\underline{\text { Heart Valves }}$}

There are 2 life saving valves in the heart that can be donated. In many cases, heart valves are used to benefit children with complex heart defects as well as adults with heart disease. This gift can free these patients of medication therapy and can give them many years of life without the complication of frequent surgeries.

\section{$\underline{\text { Pericardium }}$}

The pericardium is the thin sac that surrounds the heart. The pericardium can be used in eye surgery for repair due to trauma, bladder support surgery for female urinary incontinence, and brain surgery.

\section{Bone and associated tissue}

This gift is used in a variety of different ways such as repairing injuries to the back and in hip replacement surgery. Donated bone can also be used as a structural support for a badly broken bone. It is also used to repair serious ligament and tendon injuries, an example being ACL reconstruction.

\section{Blood Vessels of the lower extremities}

These are the saphenous and femoral veins. Donated vein is used in cardiac surgery as a graft to supply blood flow to the heart. Vein is also used in peripheral bypass surgery to supply blood to the leg and foot, saving the limb.

\section{$\underline{\text { Skin }}$}

Donated skin can be used for the treatment of burns, cleft lip repair, cancer reconstructive repair such as post-mastectomy repair, hernia repair, and certain dental procedures.

\section{$\underline{\text { Corneas }}$}

$90 \%$ of corneal blindness can be repaired and vision immediately restored with a corneal transplant. Causes of corneal blindness include congenital birth defects, degenerative disease, or injury to the eye due to trauma.

\section{$\underline{\text { Aortoiliac graft }}$}

The AI graft is used to replace infected synthetic grafts used during abdominal aortic aneurysm repair. Synthetic graft infection can be a lethal complication of AAA repair. This is a life saving tissue. 


\section{Appendix F}

\section{New England Organ Bank Tissue Screening Worksheet}

\section{ALL deaths must be reported to NEOB within 1 hour of cardiac death.} $1(800)$ 446-6362

The following information will be needed for EVERY referral:

Phone \# to Unit/Unit where patient died Name of Patient Medical Record \# Date of Birth

Date of Admission Cardiac Death Date/Time Preliminary COD/admission diagnosis

Was the patient mechanically ventilated within 24 hours of death

If you answered YES to any of these questions, or if this patient has been reported to NEOB previously during this admission, please inform the NEOB Clinical Coordinator at the beginning of your call.

\begin{tabular}{|c|c|c|}
\hline Age 96 or over & Yes & No \\
\hline$<36$ weeks gestation & Yes & No \\
\hline $\mathrm{HIV}+$ & Yes & No \\
\hline Hepatitis B or C+ & Yes & No \\
\hline IV drug use within $5 y r s$ & Yes & No \\
\hline Age $75+$ with metastatic cancer & Yes & No \\
\hline Current leukemia or lymphoma & Yes & No \\
\hline Is sepsis COD on death certificate & Yes & No \\
\hline Diagnosed with Alzheimer's & Yes & No \\
\hline
\end{tabular}

If all answers in the top box are checked $\underline{N O}$, the patient is still a potential tissue donor. Please have the patient's chart and the information listed below readily available.

\section{Clinical Course Leading to Death}

- Admitting Diagnosis, Evidence of Infection, Antibiotic Coverage, and Surgical Procedures

\section{Lab Results}

- Daily WBC's \& Daily Temperatures (most recent, 3 days of results) and Culture Results this admission

\section{Medical History}

- Past Medical History

- Current Medical Diagnoses

- Patient's Regular Home Medications

\section{Physical Assessment}

- Trauma, Deformities, Amputations

- Skin Integrity (rashes, breakdowns, ulcers, etc.), Tattoos, or Body Piercings

- Documented Height and Weight

$>$ Blood/Fluid Received (Need to have colloids and crystalloids accurately documented in the chart to determine whether or not there is a suitable blood sample available for serology testing)

$>$ Next-of-Kin Contact information (Provide \# to where family/NOK can be reached \& any additional contacts)

$>$ If ED Death we will also need the name of the EMS company, any cardiac rhythm (PEA, VFIB, est. downtime)

Tissue donation may include corneas, heart valves, aortoiliac graft, bone, vein, and skin. We ask that the potential for donation NOT be mentioned to the families at the hospital. 
Appendix G
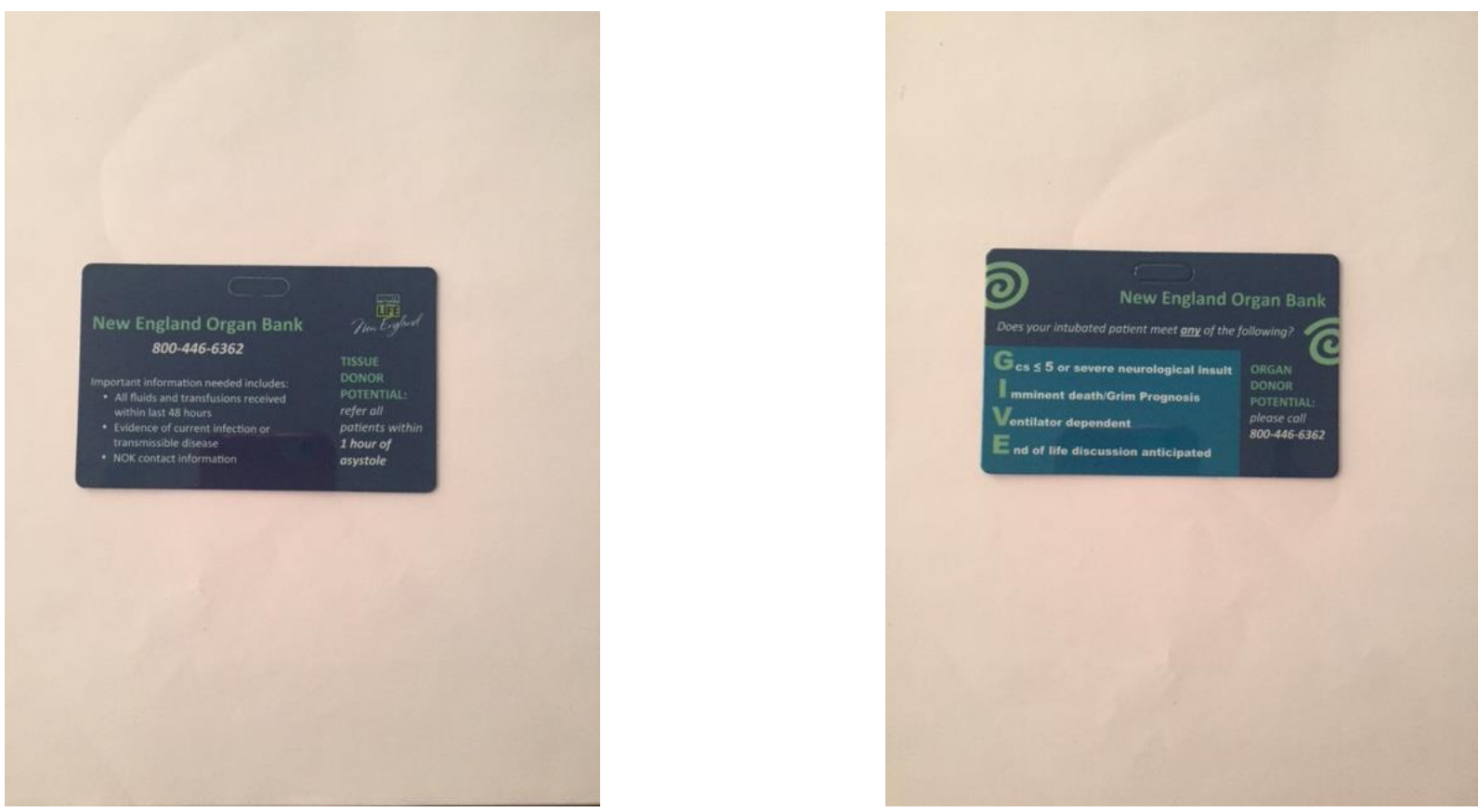
